\title{
Kontribusi konsep diri terhadap interaksi sosial siswa
}

\author{
Yopi Yulianti ${ }^{1)}$, Rezky Permata Sari ${ }^{*}$, , Tanti Ardianti ${ }^{3)}$ \\ 1,2,3) Universitas Indraprasta PGRI \\ *) rezky1023@gmail.com
}

Article History: Received: 08/04/2021; Revised: $17 / 05 / 2021$; Accepted: 11/06/2021 Published: 28/06/2021.

How to cite: Yulianti, Y., Sari, R.P., \& Ardianti, T. (2021). Kontribus konsep diri terhadap interaksi sosial siswa. Orien: Cakrawala Ilmiah Mahasiswa, 1(1), pp. 5158. DOI: $10.30998 / o c i m . v 1 i 1.4572$

\section{(c) (i) This is an open} distributed under the Creative Commons 4.0 Attribution License, which permits unrestricted use, distribution, and reproduction in any medium, provided the original work is properly cited. (c) 2021, Yulianti, Y., Sari, R.P., \& Ardianti, T.

\begin{abstract}
Abstrak: penelitian ini bertujuan untuk mengetahui hubungan antara konsep diri dan interaksi sosial siswa SMK Binakarya Mandiri 2 Kota Bekasi. Metode penelitian yang digunakan dalam penelitian ini adalah metode kuantitatif dengan instrumen berupa angket dan pengujian hipotesis dengan uji korelasi product moment. Populasi dalam penelitian ini sebanyak 223 siswa kelas XI SMK Binakarya Mandiri 2 Kota Bekasi dengan besaran sampel 45 orang siswa yang ditarik secara acak. Pada pengujian hipotesis diketahui bahwa nilai sig. sebesar 0,003. Nilai koefisien korelasi sig. 0,003 jika dibandingkan dengan probabilitas yaitu 0,05 maka 0,003 < 0,05 sehingga hipotesis altenatif diterima. Hal ini berarti bahwa terdapat hubungan antara konsep diri dan interaksi sosial siswa SMK Binakarya Mandiri 2 Kota Bekasi. Nilai koefesien korelasi berada pada 0,428 ini bermakna bahwa derajat hubungan antara konsep diri dan interaksi sosial siswa berada pada derajat sedang dan berbentuk positif.
\end{abstract}

Kata Kunci: konsep diri, interaksi sosial

Abstract: this study aim to determine correlation between self-concept to social interaction of SMK Binakarya Mandiri 2 Bekasi City students. This was quantitative research with questionnaire as instrument and hypothesis were tested by product moment correlation test. Population in this study amounted to 223 students with 45 students as samples estimated by random sampling. Hypothesis test shown that sig score 0,003 . The correlation coefficient value sig 0,003 when compared with the probability that is 0,05 then $0,003<0,05$ so that the hypothesis was accepted. This means that there was a correlation between self-concept with social interaction of SMK Binakarya Mandiri 2 Bekasi City students. The value of the correlation coefficient was 0,428 this means that the degree of correlation between self-concept and students' social interaction was at a moderate degree and was positive.

Keywords: self-concept, social interaction

\section{Pendahuluan}

Manusia sebagai makhluk sosial dalam upaya pemenuhan kebutuhan hidupnya, senantiasa dituntut untuk menjalin hubungan atau interaksi dengan orang lain. Interaksi sosial tidak bisa lepas dari kehidupan manusia, setiap sendi kehidupan dan tindakan manusia akan selalu melibatkan dan berimbas pada lingkungan begitupun sebaliknya.

Interaksi sosial merupakan suatu hubungan timbal balik yang dilakukan antara individu dengan individu, kelompok dengan kelompok atau individu dengan kelompok sehingga saling mempengaruhi satu sama lain. Bonner menjelaskan bahwa interaksi sosial adalah suatu hubungan antara dua orang atau lebih individu dimana kelakuan individu yang satu mempengaruhi, mengubah, atau memperbaiki kelakuan individu lain, atau sebaliknya (Santoso, 
2010). Melalui interaksi sosial individu dapat mengenal hal-hal baru dan mengembangkan potensinya, mendapatkan berbagai informasi penting untuk pengembangan diri dari lingkungan sosial dan menerapkan untuk masa depannya. Melalui interaksi sosial individu membangun pertemanan dan persahabatan, esensi persahabatan adalah hubungan timbal balik dan komitmen antara dua individu atau lebih yang memandang satu sama lain

Pada era digital ini, orang-orang tidak hanya berinteraksi di dunia nyata namun juga di dunia maya melalui berbagai media sosial. Melalui media sosial masyarkat berinteraksi mulai dari hanya mengobrol sampai kepada urusan jual-beli. Interaksi sosial yang dilakukan di dunia maya ini tentu saja membawa dampak positif dan negatif, dampak positif diantaranya bisa memudahkan komunikasi jarak jauh, namun di dunia maya tidak semua yang terlihat adalah benar adanya. Umumnya, di dunia maya orang-orang hanya memperlihatkan sisi baik dari diri mereka, sedangkan sisi kurang baik tidak akan di perlihatkan di dunia maya sehingga seseorang di dunia maya akan terlihat sempurna dimata orang lain dan hal ini bisa menimbulkan rasa iri, rasa minder serta merasa tidak puas terhadap diri sendiri bagi orang lain yang melihatnya dan hal ini dipengaruhi oleh konsep diri individu tersebut.

Konsep diri merupakan faktor penting dalam berinteraksi. Konsep diri sebagai cermin bagi individu dalam memandang dirinya. Individu akan bereaksi terhadap lingkungannya sesuai dengan konsep dirinya, sesuai dengan keyakinannya terhadap dirinya. Konsep diri merupakan bagian diri yang mempengaruhi setiap aspek pengalaman, baik itu pikiran, perasaan, persepsi maupun tingkah laku individu atau sebagai gambaran mental individu yang terdiri dari pengetahuan mengenai diri sendiri, penghargaan bagi diri sendiri, dan penilaian terhadap diri sendiri (Bashori \& Hidayat, 2016). Individu dalam memandang atau menilai dirinya ada yang menilai positif dan ada yang menilai negatif, individu yang menilai dirinya positif memiliki konsep diri yang positif sedangkan yang menilai dirinya negatif memiliki konsep diri negatif.

Pembentukan konsep diri memudahkan interaksi sosial sehingga individu yang bersangkutan dapat mengantisipasi reaksi orang lain. Konsep diri bukanlah sesuatu yang tibatiba muncul, pembentukan konsep diri dipengaruhi oleh orang lain (Hapsari, 2016). Sejak kecil orang tua, saudara kandung dan sanak saudara lainnya merupakan dunia sosial bagi anak-anak, maka bagaimana perasaan mereka kepada anak- anak dan bagaimana perlakuan mereka merupakan faktor penting dalam pembentukan konsep diri. Misalnya, Orang tua yang selalu mengambil keputusan untuk anaknya tanpa mengajak anaknya berdiskusi akan menyebabkan anak tidak percaya diri dalam mengambil keputusan untuk dirinya sendiri saat mulai dewasa. Setelah beranjak remaja guru dan teman-teman sebayanya juga mengambil bagian dalam pembentukan konsep diri siswa. Misalnya, seorang guru secara terus-menerus mengatakan pada seorang siswa bahwa ia kurang mampu, maka lama-kelamaan siswa tersebut akan mempunyai konsep diri bahwa dirinya tidak mampu.

Individu yang mempunyai konsep diri yang positif, biasanya lebih baik dalam melakukan interaksi dengan teman, bersikap optimis dalam menghadapi situasi dilingkungan dan tidak jarang ikut mengambil peran didalamnya. Individu dengan konsep diri positif akan dapat melakukan persepsi yang lebih cermat, mengungkapkan petunjuk-petunjuk dari orang lain dapat menafsirkan orang lain dengan cermat pula sehingga dapat memberikan respon yang sesuai terhadap orang lain atau lingkungannya. Sebaliknya individu yang memiliki konsep diri negatif, mengalami hambatan dalam proses interaksi dengan lingkungan.

Konsep diri memiliki peran penting dalam interaksi sosial dan interaksi sosial merupakan hal yang sangat dibutuhkan serta berpengaruh dalam kehidupan siswa SMK. Siswa SMK berada pada usia remaja, masa remaja merupakan merupakan peralihan antara masa kanak-kanak ke masa dewasa yang ditandai dengan perubahan aspek fisik dan psikologis. Remaja mengalami 
perkembangan dan perubahan dalam segi fisik, mental, sosial dan emosional. Masa remaja seringkali dikenal dengan fase mencari jati diri atau fase topan atau badai, dalam mencapai perkembangan yang maksimal ada beberapa tugas perkembangan remaja, salah satunya adalah mampu menerima keadaan dirirnya. Kegagalan dalam tugas perkembangan penerimaan diri akan menimbulkan konsep diri yang negatif. Cinta terhadap diri sendiri merupakan pangkal dari mencintai orang lain, dengan menerima diri sendiri barulah bisa menerima orang lain, mengenal diri sendiri penting bagi manusia sebelum mengenal orang lain, dengan memandang positif diri sendiri barulah dapat menanggapi positif orang lain setelah itu barulah terbangun interaksi sosial yang efektif. Pada kampanye terbarunya unicef mengangkat tema love MySelf, dalam kampanye ini unicef berharap anak-anak dan anak muda dapat mencintai dan menerima diri sendiri dengan positif. Berdasarkan kampanye ini jelaslah betapa pentingnya penerimaan terhadap diri yang menjadi salah satu bentuk konsep diri positif.

Konsep diri siswa akan mempengaruhi perilaku siswa termasuk pada saat kegiatan belajar mengajar dan pengalaman serta proses belajar yang dialami remaja baik berupa kegagalan maupun kesuksesan dapat membentuk konsep diri remaja. Pada lingkungan sekolah, penerimaan teman sebaya bisa diperoleh karena prestasi belajar, kegiatan ekstrakulikuler, karena penampilan fisik, namun ada juga siswa yang selalu mengikuti sikap atau perilaku yang dilakukan kelompok sebayanya hanya karena ingin diterima dalam kelompoknya. Remaja yang diterima dalam kelompok karena prestasi, penampilan fisik yang baik maupun sikap ramah dan rendah hati, akan merasa bahagia dan memiliki konsep diri yang positif. Sebaliknya remaja yang sering mendapat olok-olok dari teman atau guru, apalagi secara berulang-ulang akan tertanam dalam diri remaja gambaran diri sesuai persepsi yang orang lain berikan kepadanya.

Konsep diri negatif akan menimbulkan beberapa masalah, diantaranya kurang percaya diri. Siswa yang kurang percaya diri akan sulit bergaul, sulit untuk bersikap ramah terhadap teman dan mudah berpikiran negatif terhadap tindakan temannya serta sulit menerima kritikan. Saat dikelas, seorang siswa yang tidak percaya diri akan kesulitan untuk bertanya kepada guru ataupun menyampaikan pendapatnya tentang suatu materi pelajaran. Kurang percaya diri juga akan menghambat siswa dalam berorganisasi, dimana dalam berorganisasi seperti kegiatan ekstrakulikuler siswa dituntut untuk bisa berinteraksi dan berkomunikasi dengan baik. Siswa dengan konsep diri negatif cenderung bersikap rendah diri, merasa dirinya tidak sebaik orang lain, pesimistis dan menarik diri dari lingkungan. Hal-hal tersebut tentu saja akan menghambat aktualisasi diri siswa.

Siswa dengan interaksi sosial yang buruk akan berimbas pada pertemanan. Berteman dan bersahabat merupakan suatu kebutuhan bagi siswa SMK. Sebagai remaja, siswa SMK sangat ingin diterima dan dipandang sebagai anggota kelompok teman sebayanya. Melalui kelompok teman sebaya, remaja diharapkan mampu mengenali potensi dan berinteraksi dengan teman sebaya secara positif dan kreatif. Melalui proses mengenali diri dan pencarian wawasan sosial, kepribadian dan rohaniah maka akan terbentuk pikiran realistis dan optimis untuk menonjolkan kelebihan dan mengatasi kekurangan, sehingga seorang remaja dapat menemukan dirinya sendiri. Siswa akan merasa sangat menderita manakala tidak diterima atau bahkan diasingkan oleh teman sebayanya. Penderitaannya akan lebih mendalam daripada tidak diterima keluarganya sendiri. Kohesivitas kelompok sangat kuat dan toleransi antar anggota kelompok sangat tinggi. Remaja cenderung mudah terpengaruh oleh kelompok teman sebanya, jika remaja belum memiliki konsep diri yang baik akan semakin mudah dipengaruhi.

Di SMK Binakarya Mandiri 2 Kota Bekasi terdapat seorang siswi yang terhambat dalam pergaulannya dikarenakan konsep diri yang belum cukup baik, siswi ini hanya memiliki seorang teman dikarenakan dirinya merasa tidak cukup cantik sehingga merasa tidak percaya diri untuk 
berteman dengan banyak orang. Hal ini dikhawatirkan jika terus-menerus berlajut, akan mengakibatkan siswi ini tidak memiliki kemampuan yang baik dalam berinteraksi sosial, dimana kemampuan interaksi sosial sangat dibutuhkan untuk bisa menjalani kehidupan secara efektif.

Berdasarkan fenomena-fenomena dan analisis diatas, peneliti akan melakukan penelitian tentang Hubungan Antara Konsep Diri dengan Interaksi Sosial Siswa SMK Binakarya Mandiri 2 Kota Bekasi. Penelitian ini bertujuan untuk mengetahui apakah konsep diri berhubungan dengan interaksi sosial siswa SMK Binakarya Mandiri 2 Kota Bekasi. Hipotesis penelitian ini adalah konsep diri berhubungan dengan interaksi sosial siswa SMK Binakarya Mandiri 2 Kota Bekasi.

\section{Metode}

Penelitian ini dilakukan di SMK Binakarya Mandiri 2 Kota Bekasi pada Januari hingga Juli 2020. Penelitian ini merupakan pendekatan kuantitatif dengan jenis korelasional. Populasi dalam penelitian ini adalah siswa SMK Binakarya Mandiri 2 Kota Bekasi yang berjumlah 223 siswa. Sampel ditarik secara random dengan estimasi 20\% dari populasi (Arikunto, 2013). Untuk itu sampel dalam penelitian ini berjumlah 45 siswa. Data dikumpulkan dengan teknik angket. Angket yang dimaksudkan adalah angket konsep diri dan angket interaksi sosial. Angket konsep diri disusun berdasarkan karakteristik konsep diri (Bashori \& Hidayat, 2016) sedangka angket interaksi sosial disusun berdasarkan bentuk-bentuk interaksi sosial (Soekanto \& Sulistyowati, 2017). Kedua angket telah mengalami pengujian validitas dan reliabilitas untuk melihat tingkat kelayakan angket. Angket konsep diri memiliki skor alpha cronbach 0,823 yang artinya angket tersebut reliabel sedangkan angket interaksi sosial koefisien alpha cronbach-nya sebesar 0,584 dan dinyatakan reliabel. Data hasil penelitian dianalisis dengan menggunakan uji korelasi Pearson dengan taraf signifikansi sebesar 0,05. Pengujian dilakukan dengan bantuan aplikasi Statistical Product for Service Solution (SPSS) 20 for windows.

\section{Hasil dan Diskusi}

Bagian ini akan menjelaskan bagaimana hasil penelitian yang telah dilakukan. Berikut merupakan diagram garis yang menjelaskan tingkat konsep diri dan interaksi sosial siswa SMK Binakarya Mandiri 2 Kota Bekasi.

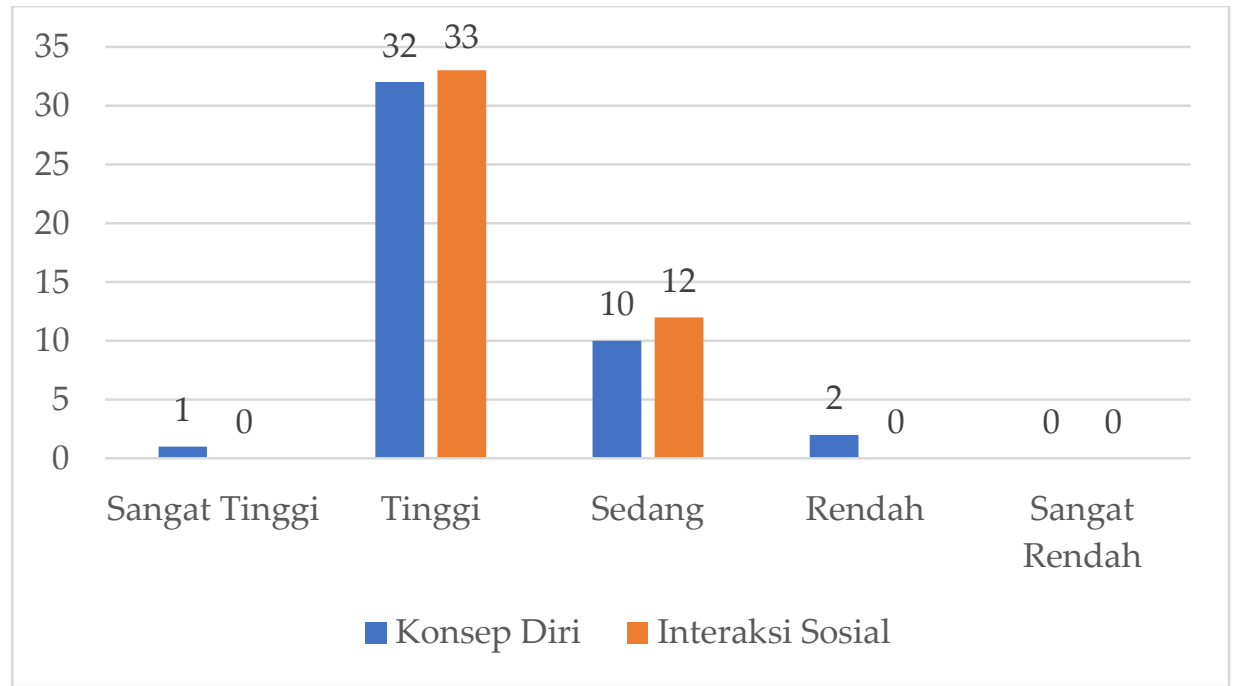

Gambar 1. Deskripsi Konsep Diri dan Interaksi Sosial Siswa 
Sumber: Diolah dari data penelitian, 2021

Berdasarkan gambar 1 diketahui bahwa pada variabel konsep diri terdapat satu siswa (2\%) yang memiliki konsep diri pada kategori sangat tinggi, 32 siswa (71\%) yang memiliki konsep diri pada kategori tinggi, 10 siswa (22\%) yang memiliki konsep diri pada kategori sedang, dan terdapat dua siswa (4\%) yang memiliki konsep diri pada kategori rendah serta tidak terdapat siswa yang memiliki konsep diri yang sangat rendah. Berdasarkan hal itu dapat dipahami bahwa secara frekuensi konsep diri berada pada kategori tinggi. Untuk variabel interaksi sosial diketahui bahwa terdapat 33 siswa (73\%) yang memiliki interaksi sosial dengan kategori tinggi, 12 siswa (27\%) yang memiliki interaksi sosial dengan kategori sedang, dan tidak terdapat siswa yang memiliki tingkat interaksi sosial pada kategori sangat tinggi, rendah, dan sangat rendah. Berdasarkan hal itu dapat dipahami bahwa secara frekuensi tingkat kedisiplinan siswa berada pada kategori tinggi.

Interpretasi hasil penelitian dalam kelompok disajikan pada tabel 1 berikut.

Tabel 1. Deskripsi Konsep Diri dan Interaksi Sosial Siswa Dalam Kelompok

\begin{tabular}{lrrrrr}
\hline \multicolumn{5}{c}{ Descriptive Statistics } \\
\hline Konsep Diri & $\mathrm{N}$ & Minimum & Maximum & Mean & Std. Deviation \\
Interaksi Sosial & 45 & 78 & 158 & 125,53 & 14,849 \\
\hline Valid N (listwise) & 45 & 76 & 99 & 87,04 & 5,402 \\
\hline \multicolumn{5}{c}{ Sumber: Diolah dari data penelitian, 2021 }
\end{tabular}

Berdasarkan tabel 1 diketahui bahwa untuk variabel konsep diri dari 45 sampel nilai terendah adalah 78 , nilai tertinggi 158, dan rata-rata sebesar 125,53. Adapun standar deviasinya sebesar 14,849 . Nilai rata-rata konsep diri bila diterjemahkan dalam norma kategorisasi berarti bahwa konsep diri berada pada kategori tinggi. Hasil ini mengambarkan secara umum konsep diri berada pada kategori tinggi. Adapun untuk variabel interaksi sosial nilai terendah adalah 76, nilai tertinggi 99, nilai rata-rata sebesar 87,04, dengan standar deviasi sebesar 5,402. Nilai ratarata interaksi sosial bila diterjemahkan dalam norma kategorisasi berarti bahwa interaksi sosial siswa berada pada kategori tinggi.

Data hasil penelitian yang telah dideskripsikan selanjutnya akan dianalisis dengan menggunakan analisis korelasi. Namun sebelum melakukan analisis korelasi terlebih dahulu akan dilakukan uji prasyarat analisis untuk menentukan teknik statistika lanjutan dalam penelitian ini. Teknik statistika lanjutan yang dimaksud adalah apakah data dianalisis menggunakan statistika parametrik atau menggunakan statistika nonparametrik. Uji prasyarat analisis korelasi dilakukan dengan uji normalitas data dan uji linearitas data.

Berdasarkan hasil uji normalitas dan linieritas dengan bantuan SPSS diketahui bahwa data berdistribusi normal dengan nilai asymp. sig. (2-tailed) sebesar 0,200. Kedua variabel pula dinyatakan berada pada hubungan yang linier melalui pengujian yang memperoleh nilai deviation from linearity sebesar 0,966. Untuk itu pengujian korelasi Pearson dapat dilakukan. Adapun hasil pengujiannya disajikan pada tabel 2 berikut.

Tabel 2. Output Pengujian Korelasi Pearson

\begin{tabular}{lllr}
\hline \multicolumn{3}{c}{ Correlations } \\
\hline \multicolumn{3}{c}{ Konsep_Diri } & Interaksi_Sosial \\
\hline Konsep_Diri & Pearson Correlation & 1 & $428^{* *}$ \\
& Sig. (2-tailed) & & 0,003 \\
& $\mathrm{~N}$ & 45 & 45
\end{tabular}




\begin{tabular}{|c|c|c|c|}
\hline \multirow[t]{3}{*}{ Interaksi_Sosial } & Pearson Correlation &, $428^{* *}$ & 1 \\
\hline & Sig. (2-tailed) & 0,003 & \\
\hline & $\mathrm{N}$ & 45 & 45 \\
\hline
\end{tabular}

Sumber: Diolah dari data penelitian, 2021

Berdasarkan tabel 2 diketahui bahwa koefisien korelasi konsep diri dengan interaksi sosial sebesar 0,428. Hal ini ini bermakna bahwa derajat hubungan antara konsep diri dan interaksi sosial siswa berada pada derajat sedang dan berbentuk positif. Diketahui pula bahwa nilai sig. korelasi sebesar 0,003. Nilai koefiseien korelasi sig. 0,003 jika dibandingkan probabilitas yaitu 0,05 , maka $0,003<0,05$ sehingga $\mathrm{H}_{0}$ ditolak dan $\mathrm{H}_{1}$ diterima. Hal ini berarti bahwa terdapat hubungan antara konsep diri dan interaksi sosial siswa SMK Binakarya Mandiri 2 Kota Bekasi.

Untuk mengetahui sumbangsih konsep diri terhadap interaksi sosial dilakukan pengujian koefisien determinasi dengan bantuan SPSS. Adapun hasilnya disajikan pada tabel 3 berikut.

Tabel 3. Output Pengujian Koefisien Determinasi

\begin{tabular}{crrrr}
\hline \multicolumn{5}{c}{ Model Summary } \\
\hline Model & $\mathrm{R}$ & $\mathrm{R}$ Square & Adjusted $R$ Square & Std. Error of the Estimate \\
\hline 1 &, $428^{\mathrm{a}}$ & 0,184 & 0,165 & 4,937 \\
\hline a. Predictors: (Constant), Konsep_Diri & & & \\
\hline
\end{tabular}

Sumber: Diolah dari data penelitian, 2021

Berdasarkan tabel 3 diperoleh nilai R square sebesar 0,184. Hal ini artinya bahwa konsep diri menyumbang 18,4\% keberhasilan interaksi sosial pada siswa. Sisanya sebesar $81,6 \%$ ditentukan faktor lain di luar penelitian ini. Selanjutnya dilakukan pengujian signifikansi untuk mengetahui apakah korelasi yang timbul merupakan hal yang signifikan atau tidak. Adapun pengujian menggunakan uji t dengan bantuan SPSS. Hasilnya disajikan pada tabel 4 berikut.

Tabel 4. Output Pengujian Signifikansi

\begin{tabular}{|c|c|c|c|c|c|c|c|c|}
\hline \multicolumn{9}{|c|}{ Paired Samples Test } \\
\hline & \multicolumn{5}{|c|}{ Paired Differences } & \multirow[t]{3}{*}{$t$} & \multirow[t]{3}{*}{ df } & \multirow[t]{3}{*}{ Sig. (2-tailed) } \\
\hline & \multirow[t]{2}{*}{ Mean } & \multirow[t]{2}{*}{$\begin{array}{c}\text { Std. } \\
\text { Deviation }\end{array}$} & \multirow[t]{2}{*}{$\begin{array}{l}\text { Std. Error } \\
\text { Mean }\end{array}$} & \multicolumn{2}{|c|}{$\begin{array}{c}95 \% \text { Confidence } \\
\text { Interval of the } \\
\text { Difference }\end{array}$} & & & \\
\hline & & & & Lower & Upper & & & \\
\hline $\begin{array}{ll}\text { Pair } 1 & \text { Konsep_Diri - } \\
& \text { Interaksi_Sosial }\end{array}$ & 38,489 & 13,451 & 2,005 & 34,448 & 42,530 & 19,195 & 44 & .000 \\
\hline
\end{tabular}

Sumber: Diolah dari data penelitian, 2021

Berdasarkan pengujian signifikansi uji-t diperoleh nilai sig. sebesar 0,000. Nilai sig. 0,000 kurang dari 0,05 hal ini bermakna bahwa terdapat hubungan yang signifikan antara konsep diri dan interaksi sosial siswa di SMK Binakarya Mandiri 2 Kota Bekasi.

Setiap manusia membutuhkan interaksi sosial untuk memenuhi kebutuhannya mulai dari yang paling dasar yaitu pangan sampai kepada aktualisasi diri. Bagi siswa SMK interaksi sosial merupakan suatu yang sangat berpengaruh dalam kesehariannya karena di masa remaja siswa sangat ingin diterima dalam kelompok teman sebayanya. Melalui kelompok teman sebaya siswa mengembangkan diri, mengenali bakat dan potensi serta berbagi hobi dan lain sebagainya.

Seorang siswa dengan konsep diri yang positif akan lebih mudah dalam berinteraksi sosial, percaya diri dalam berteman dan berani mengembangkan diri. sebaliknya siswa dengan 
konsep diri negatif akan cenderung menarik diri dari lingkungan, meragukan kemampuan yang dimiliki dan kurang percaya diri, hal ini akan menghambat aktualisasi diri siswa dimana aktualisasi dan pengembangan diri sangat dibutuhkan semasa sekolah agar siswa dapat mengoptimalkan bakat dan meraih masa depan yang dicita-citakan.

Mappiare (2006) menjelaskan bahwa konsep diri merupakan keseluruhan pola persepsi diri sebagaimana dirumuskan oleh individu itu sendiri; atau pemahaman dan pemaknaan seseorang mengenai dan yang berkaitan dengan diri. Konsep diri terdiri dari gambaran diri, ideal diri, harga diri, peran diri, dan identitas diri. Konsep diri itu sendiri akan turut berkembang dan dipengaruhi oleh banyak faktor.

Dalam kehidupan sosial konsep diri akan menjadi pendorong munculnya tingkah laku untuk berinteraksi. Ketika siswa mengonsepkan bahwa dirinya bisa maka siswa akan senantiasa terdorong untuk mampu tampil ke depan dan bersosialisasi secara positif dan aktif walaupun mungkin hasilnya kurang optimal. Hal ini tentu didukung pula oleh faktor-faktor lain. Sedangkan bagi siswa yang memiliki konsep diri yang rendah maka hal ini akan menjadikan siswa untuk menarik diri dari kehidupan sosial karena adanya rasa pesimis dalam menghadapi kehidupan yang lebih luas. Berkaitan dengan itu pada dasarnya konsep diri berpeluang memiliki kontribusi yang signifikan terhadap interaksi sosial pada siswa.

Hasil penelitian mengungkapkan bahwa konsep diri berhubungan signifikan dengan interaksi sosial siswa di SMK Binakarya Mandiri 2 Kota Bekasi. Artinya bahwa hubungan yang terjadi bersifat realistis. Melalui kajian literatur diperoleh bahwa menurut Marsh (Wang, 2007) konsep diri memiliki dua sisi dari diri, yakni perbandingan dalam diri (kerangka acuan internal) dan perbandingan sosial (kerangka acuan eksternal). Kerangka acuan internal merupakan kerangka evaluasi diri dengan mempertimbangkan aspek-aspek pada diri siswa itu sendiri semisal gambaran diri, ideal diri, harga diri, peran diri, dan identitas diri. Adapun kerangka acuan eksternal merupakan hasil evaluasi diri berdasarkan hasil interaksi dengan lingkungan. Pada penelitian yang dilakukan hanya menyentuh aspek internal konsep diri pada siswa dan belum mempertimbangkan aspek eksternal konsep diri siswa itu sendiri. Untuk itu bagi peneliti yang ingin melanjutkan penelitian ini diharapkan agar mampu melakukan penelitian dengan menjangkau aspek eksternal konsep diri itu sendiri.

\section{Simpulan}

Berdasarkan hasil penelitian diketahui bahwa konsep diri memiliki hubungan yang signifikan dengan interaksi sosial siswa SMK Binakarya Mandiri 2 Kota Bekasi. Implikasi dari hasil penelitian ini adalah pertama, kepala sekolah disarankan dapat mendukung program Bimbingan dan Konseling terkait dengan konsep diri dan interaksi sosial. Kedua, guru Bimbingan dan Konseling disarankan agar memberikan pelayanan Bimbingan dan Konseling di sekolah dengan tema terkait dengan konsep diri serta interaksi sosial agar dapat lebih mendukung terbentuk konsep diri maupun interaksi sosial siswa yang positif di sekolah. Ketiga, koordinasi antara guru Bimbingan dan Konseling dengan seluruh elemen sekolah diperlukan dalam rangka membentuk lingkungan sekolah yang mendukung terbangunnya konsep diri siswa yang positif dan interaksi sosial yang lebih efektif. Terakhir, koordinasi antara guru Bimbingan dan Konseling dengan orang tua siswa juga perlu ditingkatkan terutama dalam mendukung terbentuknya konsep diri dan interaksi sosial siswa yang positif baik di sekolah maupun di lingkungan masyarakat. 


\section{Ucapan Terima Kasih}

Penulis menyampaikan terima kasih kepada pihak SMK Binakarya Mandiri 2 Kota Bekasi baik itu kepala sekolah, guru Bimbingan dan Konseling, wali kelas, guru bidang studi maupun siswa yang dengan penuh profesionalitas telah membantu penulis dalam pelaksanaan penelitian hingga penulisan laporan penelitian.

\section{Daftar Rujukan}

Arikunto, S. (2013). Prosedur Penelitian Suatu Pendekatan Praktik. Jakarta: Rineka Cipta.

Bashori, K., \& Hidayat, K. (2016). Psikologi Sosial. Jakarta: Erlangga.

Hapsari, I. (2016). Psikologi Perkembangan Anak. Jakarta: Indeks.

Mappiare, A. (2006). Kamus Istilah Konseling dan Terapi. Jakarta: PT Raja Grafindo Persada.

Santoso, S. (2010). Teori-teori Psikologi Sosial. Bandung: Refika Aditama.

Soekanto, S., \& Sulistyowati, B. (2017). Sosiologi Suatu Pengantar. Depok: Raja Grafindo.

Wang, J. (2007). A Trend Study of Self-Concept and Mathematics Achievement in a CrossCultural Context. Mathematics Education Research Journal, 19 (3), 33 - 47.

\section{Competing interests:}

The authors declare that they have no significant competing financial, professional or personal interests that might have influenced the performance or presentation of the work described in this manuscript. 